\title{
Anger: The Theoretical Approaches and The Factors Causing the Emergence in Individuals
}

\begin{abstract}
Ahmet ÖZMEN**
ABSTRACT: In this study the knowledge that the basic psychological theories found out (put forward) has been studied on releated to the anger. After studying on the theorical knowledge, it has been discussed that what the basic factors and variables causing the emergance of feeling anger in individuals have been investigated through analysing the knowledge of the researcheres.
\end{abstract}

Key Words: Anger, causes of anger

\section{SUMMARY}

In this study, through analysing the knowledge that put forward the basic psychological theories related to the feeling anger, the factors supported by various researches causing the emergence of feeling anger individuals is discussed.

Frequency of aggressive behaviors including anger emotion increase in society. For this reason it is indispensable to study anger. Anger is the least reseached emotion in the field of psychology. In general anger is defined as malevolent or malicious and harm emotion. There are different causes

\footnotetext{
* This article is a part of a Ph.D. study which was complated in 2004 in Ankara University. The title of the doctoral thesis is "The impact of coping with anger training program based on choice theory and reality therapy and encounter group experience on students skills in coping with anger"

** Ph.D., Kafkas University Faculty of Education, ozahmet70@ hotmail.com.
} 
making people feel anger. Some of the common causes of anger include frustration, hurt, annoyance, disappointment, harassment and threats. Anger is a completely normal and usually healthy human emotion. Anger is an emotional state that varies in intensity from mild irritation to intense fury and rage. Like other emotions, anger is accompanied with physiological and biological changes. Anger emotion is a secondary one that emerges followingr frustration, hurt, annoyance, disappointment, harassment and threats.

Theoritical explanation related to anger emotion was begun to be given in 1800 s, but scientific researches started in 1970s. There are different reasons for this delay. James-Lang and Canon-Bard thoeries are the early systematic theoritical explanations related to anger emotion. In this study, the explanation of psychoanalytic theory and frusration-aggression hypothesis and social learning theory emphasising the importance of learning process and cognitive behavioral theory related to anger emotion are analysed. Later the explanation of existentialist-humanist and personcentered approaches about anger emotion are analysed. When the theoritical knowledge that have been put forward by these explanations are analysed, it can be stated that anger emotion is the one that exists in human being naturally, and such natural emotions cannot be prevented. Moreover, it is reported that prevention may also cause harm to the human beings. It is after all part of the natural response that helps our survival and helps us to protect others. However, many theoritians emphasise that the way of experience of anger has great significance, because, when it gets out of control and turns destructive, it can lead to problems.

The opinions of various researchers about the causes of anger have been given. According to Deffenbacher (1999), 1. anger can occur because of the external impulses, and 2. it can occur as a reaction to the external impulses and it can also occur as a result of the images that are created by these external impulses in some circumstances, and 3. it can only occur because of inner impulses.

Finally, it is believed that this study may contribute to the reseachers in preparing preventive programmes and in the studies of developing scala related to the subject of anger.

NOTE: This is an extended summary of the following article originally written in Turkish. 


\title{
Öfke: Kuramsal Yaklaşımlar ve Bireylerde Öfkenin Ortaya Çıkmasına Neden Olan Etmenler*
}

\begin{abstract}
Ahmet ÖZMEN**
ÖZ: $\mathrm{Bu}$ makalede, öfke duygusuna ilişkin temel psikoloji kuramlarının ortaya koymuş oldukları bilgiler incelenmektedir. Kuramsal bilgilerin incelenmesinin ardından, araştırmacıların ifadeleri doğrultusunda, öfke duygusunun bireylerde ortaya çıkmasına neden olan etmenlerin neler olduğu tartışılmaktadır.
\end{abstract}

Anahtar sözcükler: Öfke, öfkenin nedenleri.

\section{GíRiş}

Son yıllarda Türkiye ve dünyada şiddete yönelik olaylarının büyük bir hızla artmakta olduğu gözlenmektedir. Gerek yazılı ve gerekse görsel basınyayın organları aracılığıyla her gün onlarcasının haber programlarına konu olduğu şiddet içerikli bu davranışlar, toplumsal bir sorun haline gelmiştir. Şiddet içeren davranışlara çoğunlukla öfke duygusu eşlik etmektedir. Bu bakımdan öfke duygusunun ve bu duygunun bireylerde ortaya çıkmasına neden olan etmenlerin incelenmesi önem taşımaktadır.

Psikoloji sözlüğünde, öfke kavramı, "engellenme, saldırıya uğrama, tehdit edilme, yoksun birakma, kısitlama vb. gibi durumlarda hissedilen ve genellikle neden olan şeye ya da kişiye yönelik şu ya da bu biçimde

* Bu makale, 2004 yılında Ankara Üniversitesi, Eğitim Bilimleri Fakültesi'nde sunulmuş olan "Seçim Kuramına ve Gerçeklik Terapisine Dayalı Öfkeyle Başa Çıkma Eğitim Programının ve Etkileşim Grubu Uygulamasının Üniversite Öğrencilerinin Öfkeyle Başa Çıkma Becerileri Üzerindeki Etkisi” isimli doktora tezinin bir kısmından özetlenerek alınmıştır.

** Dr. Kafkas Üniversitesi Eğitim Fakültesi. ozahmet70@hotmail.com. 
saldırgan davranışlarla sonuçlanabilen oldukça yoğun olumsuz bir duygu" (Budak, 2000) olarak tanımlanmaktadır. Sözcük anlamı olarak öfke; "engellenme, incinme ya da gözdağı karşısında gösterilen saldırganlık tepkisi" (TDK, 1988), biçiminde de tanımlanabilmektedir.

Gazda'ya (1995) göre ise, öfke hoş olmayan bir duygudur. Bu duygu bir davranışın sonucu olarak ya da bir davranışın nedeni olarak ortaya çıkabilmektedir. Öfke, birçok iç ve dış etmenin etkisiyle genellikle ikincil bir duygu olarak ortaya çıkar. Diğer bir değişle öfke duygusu, korku, kaygı, üzüntü gibi çeşitli duygu durumlarını izleyen bir sonuç olarak da yaşanabilmektedir.

Korku, üzüntü ve kaygı gibi birincil duyguların sonucunda ortaya çıkan öfke duygusu, çoğu zaman bireylerin farkında olmadan yaşadıkları bir duygudur. Biyolojik olarak öfke duygusunun eşlik ettiği tepkiler genellikle, insan sinir sisteminin, içsel ve dışsal istekler, davranışlar ve baskılar karşısında verdiği bir stres tepkisi olarak değerlendirilir. Bütün bu tepkiler, insanın, psikolojik ve biyolojik güvenliğini sağlamasına ve yaşamını devam ettirmesine yardım ederler. Duygular, insan doğasında genetik olarak bulunurlar. Duyguların insan genetiğinde bulunmayan ve sonradan öğrenme yaşantılarıyla kazanılan yönü ise, bu duyguların nasıl yaşanacağıdır. Diğer bir ifadeyle insan, duygularını nasıl yaşayacağını (ifade edileceğini - ortaya koyacağını) sonradan öğrenir. Öğrenmenin etkisi en fazla öfke duygusunun yaşanması (ifade edilmesi) üzerinde kendisini göstermektedir (Gentry, 2000).

Öfke duygusunun incelenmesini zorunlu kılan gelişmeler, dünyada ortaya çıkan işçi hareketleri, Amerika Birleşik Devletlerinde ortaya çıkan insan hakları hareketi ve kadınların erkeklerle eşit haklar elde etme yönünde verdikleri mücadeleler ile birlikte hız kazanmıştır. Bu gelişmelerle birlikte, özellikle, toplumlarda hızlı bir biçimde ortaya çıkan sosyal hareketliliğin sonucu olarak, öfke duygusunun anlaşılmasına gereksinim duyulmuştur (Lulofs ve Chan, 2000).

Öfke kavramına dikkatlerin yöneltilmesiyle (1800'lü yıllar), öfkenin bir duygu olarak tek başına araştırmalara konu edilmesi (1970'li yıllar) arasında da uzunca bir sürenin geçtiği görülmektedir. Öfke kavramıyla ilgili olarak ilk kapsamlı bilimsel araştırmayı yapanların başında gelen bir araştırmacı olarak Novaco'ya (1975) göre, öfke kavramı, çok uzun bir süre, psikoloji alanında bir sorun olarak görülmemiş ve araştırmacılarca ihmal edilmiştir. Bunun nedeni ise öfkenin, uzun bir süre saldırganlık kavramının bir boyutu olarak görülmesinden ileri gelmektedir. Araştırmacılar saldırganlığı, gözleyebildikleri biçimiyle değerlendirmektedirler. Fakat öfkenin bileşenleri 
daha çok bireye özgüdür ve bu durum öfke kavramının tanımının tam ve nesnel olarak yapılmasını zorlaştırmıştır. $\mathrm{Bu}$ da araştırmacıların öfke konusunu ihmal etmelerinin en önemli nedenlerinden birisi olmuştur (Novaco, 1975).

Öfke kavramıyla ilgili olarak yapılmış olan çalışmalar incelendiğinde, bilimsel anlamda bu kavrama duyulan ilginin, 1975 y1lında Novaco ile başladığı ve günümüzde de devam ettiği görülmektedir. Öfke ile ilgili olarak birçok etmen artık psikologlarca bilinmektedir. Westermayer (2001), öfke duygusunu inceleyerek, bu duygunun, kaygıda olduğu gibi duygusal, bilişsel ve fizyolojik boyutları olan bir duygu olduğunu ortaya koymuştur. Bunun yanında Westermayer'in (2001) ifade ettiğine göre, öfke "yaşamda kalmak için kaçma davranışının karşıtı olarak mücadele gerektiren durumlarda harekete geçirici bir güç olarak da görülmektedir".

Günümüzde ise, öfke duygusu ve öfke duygusunun eşlik ettiği istenmeyen davranışlar sosyal yaşam içerisinde önemli bir sorun olarak görülmektedir. Bu sorun başta eğitimciler olmak üzere okul yöneticilerini ve anne babaları kaygılandırmaktadır. Çünkü, özellikle öfke duygusunun eşlik ettiği olumsuz davranışlar güvenli sosyal ortamları tehdit etmektedir. Bireylere öfkelerini denetim altına alma becerilerinin öğretilmesi gerekmektedir. Bu becerilerin öğretilebileceği en elverişli yerlerin başında okullar gelmektedir. Diğer yandan, okul atmosferi içerisinde yer alan bireylerin, öfke duygusunun eşlik ettiği olumsuz davranışlardan doğan çatışmalar yaşadığı ve verimlerinin düştüğü de bilinmektedir. Bu nedenle çatışmaların azaltılması için önleyici rehberlik programlarının okullarda uygulanması artık bir gereksinim halini almıştır (Bemak ve Keys, 2000).

$\mathrm{Bu}$ programların oluşturulması ve uygulamaya konulması da öfke kavramının araştırmacılar tarafından kuramsal olarak incelenmesini zorunlu kılmaktadır. Bu nedenle, bu makale kapsamında öfke duygusu kuramsal bilgiler çerçevesinde incelenmiştir.

\section{Öfke Duygusuna Kuramsal Bakış}

$\mathrm{Bu}$ başlık altında, değişik psikoloji yaklaşımlarının duyguları ve öfke duygusunu nasıl açıkladıkları konusuna yer verilecektir.

Duygularla ilgili olarak yapılan açıklamalarla karşılaştırıldığında, öfke duygusunun psikoloji alanında ele alınarak incelenmeye başlanması, oldukça yeni sayılır. Duygular üzerinde ilk kuramsal açıklamaların 1800'lü yıllarda yapıldığı görülmektedir. Oysa öfke duygusunun ele alınması ve incelenmesi ise ancak 1900' lü yılların ortalarında olmuştur. Bu nedenle bu başlık altında öncelikli olarak duyguyu açıklayan kuramsal açıklamalar başta olmak üzere 
psikolojide öfke duygusunun önemli bazı kuramlarca nasıl açıklandığı incelenecektir.

Tarihsel gelişim bakımından duygularla ilgili yapılmış olan açıklamalar incelendiğinde, kronolojik olarak James ve Lang'in duygular üzerinde yapmış oldukları açıklamaların ilk kapsamlı açıklamalar olduğu görülür. Daha sonraları James-Lang Kuramı olarak anılacak olan bu açıklamalar, James ve Lang'ın birbirlerine yakın tarihlerde, duygularla ilgili yapmış oldukları açıklamaların benzerlik göstermesinden dolayı her iki kuramcının ismiyle anılmaktadır.

James-Lang kuramı, duygularla ilgili ilk kapsamlı açıklamayı getirmesi bakımından önemlidir. Bu kurama göre, bireyin çevresindeki uyarıcılar onun bedensel tepkilerinin harekete geçmesine neden olurlar. Diğer bir ifadeyle, duygular çevredeki değişmelerin, organizma tarafından algılanmasıyla ortaya çıkarlar. Örneğin, bireyin çevresinde gördüğü korku ya da öfke yaratan bir durum, onun bedensel olarak tepkide bulunmasina yol açar. Bireyin böyle bir durumda fizyolojik olarak vereceği tepkiler, kalp atışında hızlanma, gözbebeklerinde büyüme, terleme ve soluk alış verişinde hızlanma biçiminde olur. Verilen bu tepkilerin, birey tarafından, fark edilmesi ise onda korku ya da öfke duygusunu ortaya çıkarır. Bununla beraber duygulara göre fizyolojik tepkiler de farklılık gösterirler. $\mathrm{Bu}$ açıklamada, davranışların duygulardan önce geldiği ve duyguların ortaya çıkmasını etkilediği vurgulanmaktadır. Diğer bir ifadeyle, bireyin ortaya koyduğu davranışların sonucunda, duygular ortaya çıkmakta ve yaşanmaktadır (Morris, 2002; Groves ve Schlesinger, 1982; Baron, Bryne ve Kantovitz,1981).

Cannon-Bard Kuramı olarak bilinen kurama göre, duygular ve bedensel tepkiler, birbirinden ayrı olarak ortaya çıkmazlar. Uyarıcının algılanmasından sonraki süreçte duygular ve bedensel tepkiler aynı anda ortaya çıkarlar. Örneğin (korku ya da öfke yaratan) bir uyarıcı algılandıktan sonra ortaya çıkan duyguya verilen tepki, duyguyla aynı anda gerçekleşir. Uyarıcı algılandıktan sonra ortaya çıkan duygu ve davranış arasında herhangi bir öncelik sıralaması söz konusu değildir, çünkü her ikisi de aynı anda ortaya çıkmaktadır (Morris, 2002; Groves ve Schlesinger, 1982). James-Lang ve Canon-Bard kuramları incelendiğinde, her iki kuramın da duygu-davranış ilişkisi üzerinde yoğunlaştıkları görülür. Öfke duygusuna bu kuramlar açısından bakıldığında ise, öfke duygusu içeren davranışların anlaşılmasıyla ilgili olarak, günümüzde bu kuramların ileri sürdükleri görüşlere paralel açıklamaların ve uygulamaların olduğu görülmektedir. Özellikle öfke duygusunun denetim altına alınmasında, bu duyguya eşlik eden bedensel (fizyolojik) tepkilerin kontrol edilmesinin gerektiğini ileri 
süren yaklaşımlar bulunmaktadır. Diğer duygulara oranla öfke duygusunun yaşanması sırasında ortaya çıkan bedensel değişikliklerin çok daha belirgin olmasının belki de dikkatlerin bu tepkiler üzerine yoğunlaştırılmasına da neden olduğu söylenebilir.

James-Lang ve Cannon-Bard'ın duygularla ilgili olarak yapmış oldukları kuramsal açıklamalardan sonra, psikoloji alanında en kapsamlı açıklama öfke duygusunun uzun yıllar saldırganlıkla birlikte anılmasına da neden olduğu düşünülen Sigmund Freud' un açıklamalarıdır. Bu çalışma kapsamında verilecek olan açıklamalar psikanalitik yaklaşımın içgüdülerle ilgili açıklamalarıyla sınırlı tutulmaktadır.

Psikanalitik Yaklaşımın öfke duygusu ile ilgili açıklamaları incelendiğinde bu yaklaşımın, öfke duygusunu saldırganlığın bir boyutu olarak ele aldığı görülmektedir. Psikanalitik yaklaşıma göre, insan davranışları iki temel içgüdü tarafından yönlendirilir. Bu iki temel içgüdü, biri yaşam diğeri ise ölüm içgüdüsü olarak adlandırılan eros ve tanatosdur. Freud, yaşam içgüdüsünün türevinin cinsellik, ölüm içgüdüsünün türevinin ise saldırganlık olduğunu savunur (Geçtan,1993). Brenner (1998), Psikanalitik yaklaşımın ilk yıllarında Freud'un, saldırganlığı ruhsal yaşamın bağımsız bir etkeni olarak görmemesi nedeniyle, bu kavram üzerinde cinsellik kadar durmadığını bildirmektedir.

Psikanalitik yaklaşımda öfke duygusunun işlevi daha çok bu kuramın önemli kavramlarından biri olan boşalım (katarsis) kavramı bağlamında vurgulanmaktadır. Organizmada herhangi bir gereksinim hissedildiğinde bir gerilim ortaya çıkar. Bu gerilimin ortadan kaldırılması amacıyla organizma gerginlik öncesi duruma dönmek amacıyla harekete geçer. Organizmanın önceki durumuna dönebilmesi için, bu gereksinim nedeniyle biriken enerjinin boşaltılması gerekir. Bu açıklamaları doğrultusunda psikanalitik yaklaşıma göre, öfkenin ifade edilmesi bireyde biriken enerjinin yarattığı gerilimin azalmasına yol açacaktır. Dolayısıyla öfke, biriken bu enerjinin boşaltılmasının bir yolu olarak görülür. Biriken enerjinin ifade edilmesi bireyde bir boşalım (katarsis) ve rahatlama sağlayacaktır. Öfke, psikanalitik bakış açısıyla içgüdüsel bir güçtür. Psikanalitik yaklaşımda öfke duygusunun ortaya konulması, organizmaya ait bir katarsis aracı olarak yorumlanmaktadır (Dykeman, 1995; Mayne ve Ambrose, 1999; Lulofs ve Chan, 2000).

Psikanalistler, Lorenz (1966) ve Goldberg'te (1974) dahil olmak üzere, Freud'un saldırgan enerjinin birikmesini, katarsis kavramılla bağlantılı olarak açıklamasını kabul etmektedirler (Akt. Tsai, 2000). Tsai'nin (2000) bildirdiğine göre, öfkenin ifade edilmeyerek bastırılması enerjinin içte 
tutulması içsel baskıyı yükseltirken, birey onu kontrolde tutmak için yoğun bir enerji harcar. Öfkenin bastırılması, birey için tehlikeli ve sağlıksız bir durum ortaya çıkarır. Psikanalitik yaklaşıma göre, öfkenin sürekli bir biçimde bastırılması psikolojik ve fizyolojik sağlığın bozulmasına yol açar. Psikanalitik yaklaşım öfkeyi, önemli ve ifade edilmesi gereken bir duygu olarak görür. Freud'un açıklamalarına paralel açıklamaları bulunan Lorenz'e göre insanda var olan saldırganlık, sürekli akan bir enerjinin beslediği bir içgüdüdür. $\mathrm{Bu}$ içgüdüde birikmiş olan enerjinin, belirli bir düzeye ulaştığında herhangi bir dış uyaran olmaksızın bir patlama biçiminde ortaya çıkma olasılığı da vardır (Akt.Tsai, 2000).

Psikanalitik yaklaşımın açıklamalarında, öfkenin içte tutulmasının organizma üzerinde pek çok olumsuz sonuçlarının olabileceği anlaşılmaktadır. Öfke ve saldırganlıkla ilgili önemli açıklamalardan bir diğeri ise engellenme-saldırganlık hipotezi' dir.

Engellenme-saldırganlık hipotezi, psikanalitik yaklaşımı temel alan bir görüştür. Psikanalitik yaklaşımın daha sonraki temsilcileri, "herhangi bir amaca ulaşma çabası engellendiğinde bireyde incitme davranışını güdüleyen bir öfke duygusu ortaya çıkar" biçiminde bir hipotezi ortaya atmış ve savunmuşlardır. Engellenme saldırganlık hipotezi ile ilgili açıklamalar incelendiğinde, yapılmış olan açıklamaların iki yönünün bulunduğu görülmektedir. Bunlardan biri, öfkenin olağan nedeni engellenmedir. İkincisi ise, öfke ve saldırganlığın doğuştan gelen bir dürtü olduğu ve amacına ulaşıncaya kadar süren bir enerji biçimi özelliği taşımasıdır (Akt. Atkinson ve diğerleri,1993). Son yıllarda özellikle bilişsel davranışçı yaklaşıma dayalı, engellenme-öfke hipotezinin her durumda geçerli olmadığını ortaya koyan açıklamalar bulunmaktadır. Bilişsel davranışçı yaklaşıma dayalı açıklamalarla bu hipotezin öne sürdüğu görüşler birçok noktada çelişmektedir. Bilişsel davranışçı yaklaşıma göre birey, engellenme yaşadığı durumda, engellenmesinin nedeninin mantıklı olduğunu anlarsa, öfke ve saldırganlık tepkisi ortaya çıkmayabilir.

Öfke ve saldırganlığı içgüdülerle açıklayan yaklaşımların dışında, öğrenme süreçlerini ön plana çıkararak açıklayan yaklaşımlar da bulunmaktadır. Bu yaklaşımların arasında sosyal öğrenme kuramı önemli bir yer tutmaktadir.

Sosyal Ö̆̆renme Kuramına göre, davranışlar, bireyin çevresinde gözlemlediği davranışları taklit yoluyla model alması ile kazanılır. Öğrenilmiş olan öfke ve saldırganlık içeren bir davranışın ortaya konulmasını ise bireysel ve çevresel faktörler etkilemektedir. Gözlenmiş olan öfke içerikli davranışın ya da öğrenilmiş olan bir davranışın ortaya 
konulmasında, bireyin kendi benliğini algılayışı, karşı karşıya olduğu durum ve diğer çevresel etmenler önemlidir. Birey bütün bu etmenleri değerlendirerek, öfke içerikli tepkilerini ortaya koyup koymamaya karar vermektedir. Bandura'ya göre, diğer bütün tepkilerde olduğu gibi birey, öfke ve saldırganlık içeren tepkilerini de ortaya koyarken, öz kontrol becerilerini ve (aynı zamanda durağan olmadığına inandığı) benlik algısını dikkate alarak, durumdan duruma değişiklik gösteren davranışlar gösterebilmektedir. $\mathrm{Bu}$ durum özellikle Bandura'nın saldırgan davranış ve öfke tepkilerinin ortaya konulmasıyla ilgili olarak yaptığ 1 deneylerle de ortaya konulmuştur (Akt. Baron, Bryne ve Kantovitz, 1981). Öfke duygusu üzerinde öğrenme süreçlerinin daha çok önemli olduğunu vurgulayan yaklaşımlardan bir diğeri ise, Bilişsel Davranışçı yaklaşımdır.

Bilişsel Davranışç Yaklaşım'a göre, yaşamda karşılaşılan çeşitli durumlar bireylerde farklı heyecansal tepkilere yol açar. Bu durum bireylerin duygularını da farklı biçimlerde ortaya koymalarına neden olur. Bireylerin nasıl tepkide bulunacağını, durumlara ve olaylara ilişkin algıları ve onlara yüklediği anlamlar belirler. Duyguların temelini bireyin algıları ve olaylara verdiği anlamlar oluşturur. Tüm duygusal durumlarda sinir sistemi uyarılmaktadır, fakat bireyin nasıl tepkide bulunacağına ilişkin ipuçları, bireyin içinde bulunduğu koşullar tarafından, diğer bir değişle çevre tarafından belirlenir (Morris, 2002). Bu tartışma bireylerin yaşamda karşılaştıkları olaylara ilişkin bilişsel değerlendirmelerinin, olaylara verecekleri tepkiler üzerindeki önemini ortaya koymuştur. Schachter ve Singer, duyguların farklılaşmasında, bilişsel değerlendirmelerin önemini ortaya koymaya çalışmışlardır. Yapmış oldukları deneysel çalışmalarla, duygusal tepkiler üzerinde bilişsel süreçlerin ve otonom uyarılmanın aynı zamanda oluştuğunu ortaya koymuşlardır (Akt. Atkinson, Atkinson, Smith ve Bem, 1993).

Bilişsel yaklaşımda öfke duygusu ise, daha çok fizyolojik, davranışsal, bilişsel ve duygusal yapının ortak bir sonucu olarak görülmektedir. Bu açıdan öfke, kontrol altına alınması gereken bir duygudur. Bunu da, öğrenme ilkelerine göre, bireyin öfke içeren davranışının altında yatan temel düşüncenin değiştirilmesi yoluyla gerçekleştirir. Bilişsel davranışçı yaklaşımların, öfkenin, özellikle ifade biçimi üzerinde yoğunlaştıkları görülmektedir. Bu yönüyle öfkenin ifade edilme biçiminin, öğrenilmiş bir davranış olduğu görüşünde birleşirler (Dykeman, 1995; Mayne ve Ambrose, 1999).

Bilişsel davranışçı yaklaşımın önemli kuramcılarından biri olan Beck'e (1979) göre ise, klasik davranışçılar duygu ve davranışların açıklanmasını sadece uyarıcı- tepki koşullanması modeliyle yapmışlar ve duygusal tepkileri 
dıș uyaranlara verilen tepkiler olarak açıklamışlardır. Klasik davranıșçı yaklaşımın açıklamalarında, düşüncelerin ve dış uyarıcıların birey tarafından anlamlandırılması süreçlerine yer verilmemektedir. Fakat bilişsel davranışçı yaklaşıma göre, öfke duygusunun ortaya çıkmasına neden olan şey uyarıcı değildir. Öfke duygusunun ortaya çıkmasına neden olan şey, bireyin bu uyarıcıyı algılama biçimi ve uyarıcıya verdiği anlamdır (Beck, 1979). Akılcı duygusal terapiye göre de, bireyde öfke duygusu gibi olumsuz bir biçimde ifade edilme olasıllı̆̆ bulunan duyguların yaşanmasına yol açan şey, bireyin karşı karşıya kaldığı olay ya da durumlar değil, olay ve durumlara bireyin yüklemiş olduğu anlamlardır (Novaco,1975, Beck, 1995; Deffenbacher, 1999). Bilişsel davranışçı yaklaşımda bildirildiği gibi, öfke duygusu içeren tepkilerin, bireyin olayları algılayış biçimiyle ilgili olduğunun vurgulanması, öfke duygusunu anlamada ve onu denetim altına almada önemli kolaylıklar sağlamaktadır. Yukarıda yer alan kuramsal açıklamaların dışında genel olarak duygulara ve öfke duygusuna farklı bir bakış açısı sunan varoluşçuinsancıl yaklaşım önem taşımaktadır. Bu yaklaşımın açıklamaları daha çok felsefi olsa da, birçok uygulamada temel alınması bakımından önemli bir yere sahiptir.

Varoluşcu-insancıl yaklaşıma göre, insan, kendi varlığının, ne yapmakta olduğunun ve kendisine neler olduğunun bilincinde olan bir varlıktır. Bunun sonucu olarak birey, kendisine ve çevresindeki olaylara ilişkin kararlar verme ve kendi sorumluluğunu üstlenme yeteneğine sahiptir (Geçtan, 1988).

Varoluşçu yaklaşımın önde gelen isimlerinden olan Fritz Perls'e göre insan, çoğu kez başkalarına yansıttığı öfke gibi olumsuz duyguları da dahil, tüm duygularının sorumluluğunu üstlenmelidir. Birey, başkalarına yönelik öfke duygusunun eşlik ettiği, kendisine yönelik eleștirici tutumlarını kabul etme sorumluluğunu üstlenmediği için, bu duygularını başkalarına yansıtır. Diğerlerinin öfkeli olduğuna inanır. Birey kendisinin değilmiş gibi yaşadığı öfke duygularını kendisine mal ettikçe zenginleşir. İnsan kendisini kendi dünyası içinde algılar. Bunu yapamadığı oranda da Heidegger' in varoluş suçluluğu dediği olguyu yaşar (Geçtan,1990).

Birey merkezli yaklaşıma göre, insan doğası doğuştan iyidir ve çevresiyle iyi ilişkiler kurabilir. İnsan, yaşamı süresince karşılaştığı olumsuz koşullar sonucu, diğer insanlara karşı, öfkeli, bencil ve etkisiz tutumlar geliştirebilir. Birey çevresinden kendisine yönelen etkileri fark ettiğinde, otomatik tepkiler vermek yerine tepkilerini kendisi seçer. Geliştirdiği amaçlar doğrultusunda da çevresini yönlendirir (Geçtan,1993). 
Birey merkezli yaklaşıma göre, öfke duygusunun, bireyin yaşamında bir görevi vardır. Öfkenin bireyin yaşamında hangi işlevi yerine getirdiğinin anlaşılması önemlidir. Bu nedenle birey için öfkenin kendi yaşamındaki yerinin anlaşılması ve açıklığa kavuşturularak bireyin bunu fark etmesi gerekir. Birey merkezli yaklaşımda, öfke duygusu ve bu duygunun sonucunda ortaya konulan tepkiler, benlik saygısının düşmesine yol açan incitici durumlara karşı verilen bir tepki olarak değerlendirilir (Ohrnstein, 1999).

Kuramsal yaklaşımların öfkeyi farklı yönleriyle ele almalarına karşın, öfkenin "içsel ya da dışsal uyaranlara karşı bireyin vermiş olduğu biyolojik, psikolojik ve sosyal bir tepki” olduğu görüşünde birleştikleri görülmektedir.

\section{Bireylerde Öfkenin Ortaya Çıkması (Öfkenin Nedenleri)}

Öfkenin ortaya çıkmasına neden olan durumlar farklı araştırmacılar tarafından farklı biçimlerde açıklanmaktadır. Bu kısımda, bu araştırmacıların açıklamalarına yer verilerek tartışılmaktadır.

Öfkenin ortaya çıkmasına neden olan durumları inceleyen ve genel bir sınıflandırma yapmış olan Deffenbacher (1999), öfkenin ortaya çıkışının üç biçimde gerçekleşebileceğini ileri sürmektedir. Deffenbacher'e (1999) göre, öfkeyi ortaya çıkaran uyarıcıları üç grupta incelemek gerekir. Bu uyarıcılar aşağıdaki biçimde açıklanabilir:

1. Öfke bazı durumlarda dış uyarıcılar nedeniyle ortaya çıkabilir: Herhangi bir dış uyarıcı tarafından bireyin amacına ya da isteğine ulaşmasının önlenmesi, herhangi bir iş için sırada uzun süre bekletilme, yoğun bir trafikte sıkışıp kalma ve ulaşacağı yere zamanında ulaşamama, yine başka birinin sert eleştirisine maruz kalma, konuşmalarının başka biri tarafından sık sık yarıda kesilmesi gibi davranışlarla karşı karşıya kalan birey öfkelenebilir. Bu başlık altında ele alınan dış uyarıcılar olarak ifade edilenler, sadece bireylerin karşılaştıkları olay ya da olgular değil, bireylerin çevrelerinde bulunan nesneleri de kapsamaktadır. $\mathrm{Bu}$ nesneler bazı durumlarda dış uyarıcı olarak bireylerin öfkelenmelerine neden olabilirler. Örneğin; bireyin bilgisayarının bozulması ya da acelesi olan bir bireyin arabasının çalışmaması bireyde öfke yaratabilir. Bunların tümü öfkeyi ortaya çıkaran diş uyarıcılar olarak ele alınabilir.

2. Öfke bazı durumlarda dış uyarıcıların etkisi ve bu dış uyarıcıların bireyde oluşturduğu imgeler ve geçmişe ait çağrışımların etkisiyle ortaya çıkabilir: $\mathrm{Bu}$ durumun en açık örnekleri, travma sonrası stres yaşayan bireylerde görülür. Bu bireylerin travmatik yaşantıya yol açan uyarıcılara benzer uyarıcılarla ya da o uyarıcıyı çağrıştıran farklı uyarıcılarla karşılaşması durumunda, ortaya çıkan güçlü tepkilerinden bazıları, içinde 
öfke duygusunu barındırabilir. Öfkenin dış uyarıcıların etkisi ve bu dış uyarıcıların bireyde oluşturduğu imgeler ve geçmişe ait çağnışımların etkisiyle ortaya çıkmasına, günlük yaşamdan da bir çok örnek verilebilir. Daha önceki yaşantılarından kocasına güvenini kaybetmiş olan bir kadının, kocası başka bir kadınla konuştuğu zaman şiddetli bir biçimde kıskançlık ve öfke yaşaması bu duruma örnek olarak verilebilir.

3. Bireyde, iç uyarıcıların etkisiyle ortaya çıkan öfke, düşünce ve duygularla, harekete geçirilir: Örneğin bir birey bir süre beraber olup daha sonra ayrılmış olduğu eski eşini düşündüğünde öfkelenebilir. Bazı durumlarda öfke, diğer duygular tarafından başlatılabilir. Birey yaptığı / yapacağı kötü bir işi düşünürken öfke duyabilir. Birey başka birinin kendisini eleştirisinden ve reddetmesinden korktuğu için öfke ya da savunma biçiminde tepkiler gösterebilir. Bu durumların her ikisinde de yaşanan öfke duygusu diğer duyguların tetiklemesiyle ortaya çıkmaktadır (Deffenbacher, 1999).

Deffenbacher'in (1999), öfkeyi ortaya çıkaran etmenler ve duygu durumlarının, sistemli bir biçimde sınıflamasını yapmış olduğu görülmektedir. $\mathrm{Bu}$ sınıflama incelendiğinde Deffenbacher'in (1999) öncelikle, genel bir sinıflama yaparak, daha sonra bu sinıflamaların içerisinde yer alabilecek özel durumları açıklama yoluna gittiği görülmektedir. Deffenbacher'in (1999) sınıflamasının diğer önemli bir özelliği ise, bu sınıflamanın bireyde öfkeyi ortaya çıkaran uyarıcıları, özelliklerine göre sınıflandırmış olmasıdır. Fakat, öfkeyi ortaya çıkaran etmenler ve duygu durumlarının sınıflandırmasını daha özel bir biçimde Gazda (1995) tarafından yapılmış olduğu görülmektedir.

Gazda’ya (1995) göre bu etmenler aşağıda yer alan dört başlık altında sıralanmaktadır: $\mathrm{Bu}$ başlıklar altında öfkeyi ortaya çıkaran durumlar verilerek ayrıca bunların ne kadar geçerli olup olmadığı konusu da kısaca tartışılmaktadır.

1.Kayıplar: Bireyin yaşamında önemli olan ve sevilen birinin ölümü, fiziksel bozukluklardan dolayı ortaya çıkan kayıplar, bireyin işini kaybetmesi gibi kayıp durumları bireyde, acı, üzüntü ve yas duygularının yaşanmasına yol açar. Bir kayıp durumu karşısında bireylerde genellikle öfke duygusu ortaya çıkabilir. Kayıplar karşısında bireyde öfke duygusunun dışında diğer olumsuz duygularında ortaya çıkma olasılığının olduğu unutulmamalıdır.

2.Tehditler-Korkular: Bireyin etkisinde kaldığı yasadışı olaylar, saldırıya uğraması, savaş ya da uzun süre işsiz kalma... gibi durumlardan kaynaklanan kaygı, korku ve güvensizlik duygularının bir sonucu olarak 
öfke duygusu yaşanabilir. Öfke konusunda yapılan açıklamalara bakıldığında, "saldırıya uğramak ve tehdit edilmek öfkeye neden olur" açıklaması en temel yargılardan birsidir. Fakat bu yargının çoğunlukla böyle olmadığı görülmektedir. Saldırı ve tehditler karşısında bireyler çok çeşitli tepkilerde bulunabilirler. Örneğin; birey fiziksel ya da sözlü bir saldırıya uğradığında öfkelenebilir ve karşı saldırıya geçebilir. Yine saldırıya uğramış bir birey şok olmuş ya da fiziksel bir mücadelede yenildikten sonra kendini sadece üzgün hissetmiş olabilir.

3.Engellenme: Bireyin gereksinimlerinin giderilmesi engellendiğinde yaşadığı çaresizlik ve yetersizlik duygularının sonucu olarak öfke duygusu ortaya çıkar.

Fakat öfkeye neden olan etmenlerden biri olarak görülen engellenme konusunda "engellenme öfkeye yol açar" yargısı dikkatli bir biçimde incelendiğinde, bu yargının her zaman geçerli olmadığı, sadece bazı sınırlı durumlarda geçerli olduğu görülmektedir.

4.Reddedilme: Öfke, bireyin başka biri tarafından reddedilmesi durumunda yaşadığı incinme, çöküntü ve değersizlik ve hayal kırıklığı duygularının sonucu olarak ortaya çıkabilir.

"Reddedilme öfkeye neden olur" yargısının da tartışılması gereken bir yarg1 olduğu açıktır. Ellis' e (1962) göre, reddedilme sonucu yaşanan hayal kırıklığına neden olan durumun (olayın) akılcı (mantıklı) olduğu doğrulanırsa, insanlar bu reddedilme durumuna öfkeyle karşılık vermeyeceklerdir. Örneğin; akşam evine geldiğinde yemeğin hazır olmadığını görüp, genellikle eşine öfkelenen bir koca, eşinin yemek hazırlayamayacak kadar hasta olduğunu fark ederse öfke yaşamayacaktır (Akt.Beck,1979). Bu durumda öfkelenmeye neden olan durumlara, bireyin akılcı yaklaşıp yaklaşmamasının da öfkenin ortaya çıkmasında etkili olacağı söylenebilir.

Beck'e (1979) göre bireylerde öfkeye neden olabilecek durumlar doğrudan ya da dolaylı etkileriyle öfkeyi ortaya çıkarırlar.

1. Öfkenin ortaya çıkmasına doğrudan etkide bulunan etmenler: Bireyin hoş olmayan yaşantılarla yüzleşmesi ve bu yaşantılarda rol alan asıl uyarıcının, bireyde hoş olmayan bir yaşantıya yol açması, öfkenin ortaya çıkmasında etkili olmaktadır. Bu asıl uyarıcı ise bir fiziksel saldırı, eleştiri, bask1, engelleme, reddedilme, yoksun bırakma ya da bir karşı koyma olabilir. Bu durum bireyde öfke yaşanmasına neden olur. Çünkü bu uyarıcılar bireyin güvenliğini ve gereksinimlerini örtük bir biçimde tehdit eder, birey tarafından doğrudan, kendi özgürlüğüne yöneltilmiş bir tehlike olarak algilanır. 
Öfkenin ortaya çıkmasına doğrudan etkide bulunan bir diğer grup durum ise, bireyin kendi haklarına doğrudan saldırı olarak yorumladığı komutlar ve sınırlamalardır. Otorite durumunda olan kişi tarafından yapılan bir sınırlama ya da yasaklanmış bir etkinlik, yasaklamadan etkilenen bireyde öfke yaratabilir.

Öfkenin ortaya çıkmasına doğrudan etkide bulunabilecek durumlara örnek olarak; bir genç yetişkinin herhangi bir fiziksel saldırıya uğraması, bir öğrencinin öğretmeni tarafından derste birkaç arkadaşıyla beraber ıslık çaldığı için azarlanması, bilet için sırada bekleyen bir tiyatro severin bileti almasına arkasından iterek engel olunması, bireyin sevgilisi tarafından reddedilmesi, istemediği halde bir çocuğun oyuncaklarını kardeşiyle paylaşarak birlikte oynamasının istenmesi, yeni bir politika üretmeye çalışan bir grup üyesinin diğer bir üye tarafından engellenmesi vb. verilebilir

2. Öfkenin ortaya çıkmasına dolaylı yoldan etkide bulunan etmenler: $\mathrm{Bu}$ dolaylı etmenler ise, bireyin kendisinden kaynaklanan ya da diğerleri tarafından yöneltilen uyarıcıların karşılıklı etkileşimini içermektedir. Özellikle bireye başkaları tarafından yöneltilen birçok davranış vardır ki bunlar ilk bakışta doğrudan bir saldırı olarak algılanmazlar. Bireye yöneltilen bu davranışların her birinin anlamlandırılması, bireyin bu durumları kendisine bir saldırı olarak algılayıp algılamamasına bağlıdır. Başkaları tarafından kendisine yöneltilen bu davranışların sonucunda, kendi benlik değerinin düştüğünü algılaması da öfkeyi ortaya çıkaran etkenlerden biri olarak görülür.

Beck' in (1979) söz ettiği bu dolaylı etki durumlarına örnek olarak; bireyin düzenlediği bir partiye davet ettiği misafirinin, kendisine karşı dolaylı yollarla bilgiçlik taslaması sonucu kendisini incinmiş hissetmesi, bir arkadaşlarının işindeki başarılarıyla ilgili anlattığı başarı öykülerinin dinleyenlerde uyandırdığı duyguların öfkeye dönüşmesi, kız arkadaşının başka bir erkekle neşeli bir biçimde sohbet ettiğini gören bir gencin hissettiklerinin öfkeye dönüşmesi, güzel hazırlanmış bir kahvaltı beklerken, eşinin hazırlamaması nedeniyle kahvaltı yapamayan bireyin eşine kırılması sonucunda öfke yaşaması, verilebilir. Ayrıca Beck'e (1979) göre bireyin yapılan herhangi bir davranışı (gerçekte bir tehdit olmadığı halde) varsayımsal olarak kendisine tehdit biçiminde algılaması da bireyde öfkeye yol açabilmektedir. $\mathrm{Bu}$ durum şu örneklerle açıklanabilir; dur işaretinde geçen bir motorlu aracı uzaktan gören yayanın öfkelenmesi, sofrada yemek yeme kurallarına uymayan çocuklarına sinirlenen ana -babanın öfkelenmesi, kendini bir yasaya ya da bu yasada yer alan bir uygulamaya adamıs bir kişinin binlerce mil uzakta bir ihlalin işlendiğini duyduğunda, öfkelenmesi vb. gibi. 
$\mathrm{Bu}$ açıklamalardan da görüldüğü gibi, Beck'in ikinci grup olarak değerlendirdiği bu olayların hiç biri bireye karşı kesin ve doğrudan bir tehdit oluşturmaz, fakat birey bu durumlar karşısında doğrudan bir saldırıya uğramış gibi tepki verebilir. Örneğin; yayanın hız yapana öfkesini, "o sırada caddeden karşıya geçen ben olabilirdim ya da gelecekte böyle bir durumla ben karşılaşabilirim" biçiminde açıklaması. Bu gibi varsayımsal tehditlerin ortaya çıkardığı öfke durumunun insan ilişkilerindeki anlaşmazlıklardaki payı oldukça yükssektir (Beck,1979).

Lewis ve Michalson'un (1983) öfkeyi ortaya çıkaran etmenler olarak belirttikleri durumlar incelendiğinde, bu durumların diğer sinıflamalardan çok daha özel durumlar olarak belirtildikleri görülmektedir. Bu yönüyle Lewis ve Michalson'un (1983) sinıflamaları, Gazda (1995) tarafından belirtilmiş olan sınıflamayla benzerlikler göstermektedir. Lewis ve Michalson'a (1983) göre öfke duygusunun ortaya çıkmasına neden olabilecek dört etken şu biçimde sıralanabilir; (1) Fiziksel saldırıya maruz kalma. (2) Sözel bir çatışma ortamında bulunma; Örneğin, alay edilme. (3) Reddedilme, diğerleri tarafından değerli olmadığı mesajlarının verilmesi ya da bireyin kendisinin böyle bir algıya sahip olması. (4) Emir ve yaptırımlara boyun eğmek zorunda kalmak, bireye, istemediği bir şeyi yapması yönünde baskı ya da zor kullanılması.

Spielberger'e (1980) göre ise, öfke duygusunun temelinde, "başkalarının gözündeki kişilik değerimin düşmemesi için hata yapmamalıyım" gibi bir düşünce biçimine de rastlanmıştır. Bireyin kendisini kanıtlamasının gerekli olduğuna inanmasının, başkalarının kendi mutluluğunu engellediğine inanmasının ve ilişkilerinin planlandığı gibi yürümesi gerektiğine ilişkin düşünce biçimlerinin, öfkenin ortaya çıkmasını kolaylaştırdığı ileri sürülmektedir (Akt. Özer, 1994a).

Yukarıdaki açıklamalardan anlaşılacağı gibi, öfke duygusunun ortaya çıkmasında etkili olabilecek birçok etmen sayılabilir, fakat burada en önemli kabul edilen sinıflamalara yer verilmiștir. Bu sinıflamalar incelendiğinde, Lulofs ve Chann'ın (2000) açıklamaları başka bir tartışmayı da beraberinde getirmektedir. Onlara göre; öfke duygusu bireyde var olan denge durumunun bozulmasının sonucunda ortaya çıkar. Öfkenin sözel ve fiziksel tepkilerle ya da zihinsel süreçlerde nasıl bir ifade bulacağı önemlidir. Bu nedenledir ki bilişsel süreçler öfkenin en iyi kontrol edileceği yerdir. Örneğin; bireyin beklediği birinin geç kalması, bireyde hayal kırıklığı yaratan bir durumun ortaya çıkması ya da başka biri tarafından incitilmesi durumunda nasıl tepkide bulunacağı, tamamen onun bilişsel süreçleriyle ilgilidir. $\mathrm{Bu}$ durumlara bireyin getireceği yorum ve açıklamalar, bireyin öfkelenip öfkelenmeyeceğini ya da öfkesini nasıl ifade edeceğini belirleyecektir. Başka 
biri tarafından incitilen bireyin, bu kişinin davranışlarının arkasında bir kast olabileceğini düşünmesi onun vereceği tepkinin niteliği üzerinde önemli bir rol oynamaktadır. Bireyin bu davranışa vereceği tepkide, bu davranışa ya da davranışı yapan bireye yönelik olarak yaptığı yüklemeler oldukça etkili olmaktadır. Eğer birey karşı karşıya kaldığı bu davranışın gerçekten kendisini incitmek amacıyla yapıldığı kanısına varırsa, vereceği tepki büyük olasılıkla öfke tepkisi olacaktır.

\section{Sonuç}

$\mathrm{Bu}$ çalışmada, önce temel psikoloji yaklaşımlarının öfke duygusuna bakışı incelenmiştir. $\mathrm{Bu}$ incelemeden elde edilen sonuçlar; 1. Öfke duygusunun insanın doğasında var olduğu, 2. Öfke duygusunun hiçbir zaman yok sayılamayacağı, 3. Öfke duygusunun ortaya çıkışının ya da yaşanmasının engellenemeyeceği biçiminde sıralanabilir. $\mathrm{Bu}$ açıdan bakıldığında öfkenin ortaya çıkmasının engellenmesinin doğru olmayacağı ve bu engellemenin bireyin doğasına zarar verebileceği söylenebilir. Diğer yandan, öfke duygusunun ortaya çıkmasını etkileyen etmenler konusunda, çeşitli araştırmacılarca ortaya konulmuş olan bilgilerin incelenmesi sonucunda; Beck'in (1979); Deffenbacher'in (1999); Lulofs ve Chan'in (2000) açıklamalarının daha genel etmenler üzerinde yoğunlaştığı, Spielberger'in (1980); Lewis ve Michalson'ın (1983); ve Gazda'nın (1995) açıklamalarının ise daha özele indirgenerek birebir durumların tanımlanması biçiminde olduğu görülmektedir.

Bu makalenin, öfke duygusuyla ilgili deneysel çalışmalarda ya da ölçek geliştirme çalışmalarında, kuramsal alt yapının oluşturulması bakımından önemli katkılarının olacağına inanılmaktadır. Türkiye'de 2004 yılında yayınlanan Birleşmiş Milletler Nüfus Fonu tarafından desteklenen ve Türkiye Bilimler Akademisi tarafından yürütülen bir çalışmanın sonuçlarının yer aldığı, Ergen ve Ruhsal Sorunları-durum saptama çalışması- raporlarında bildirildiğine göre, ergenlerin risk faktörleri arasında hırçın ve sinirli olma gibi psikolojik özelliklerin sayılmış olması dikkat çekicidir (TUBA Raporları, 2004). Aynı raporda gençlere yönelik önleyici programların geliştirilmesi de öneri olarak bildirilmektedir. Araştırmacıların bu tür önleyici programları oluşturmasında, bu makalede sunulmuş olan kuramsal bilgilerin faydalı olacağına inanılmaktadır. 


\section{KAYNAKLAR}

Atkinson, R.L., Atkinson, R.,C., Smith, E.E., Bem, Daryl J. (1993). Introduction to Psychology. Orlando. Harcourt Brace \& Company.

Baron, R. A., Bryne, D., Kantovitz, B.H. (1981). Psychology, understanding behavior. Tokyo. Holt-Saundars Japan.

Beck, A., T. (1979). Cognitive therapy and the emotional disorders. Boston: International University Press.

Beck, J.,S. (1995). Bilişsel terapi. Temel ilkeler ve ötesi.(Çev: N.Hisli Şahin) Ankara: Türk Psikologlar Derneği Yayınları (2001).

Bemak, F. , Keys, S. (2000). Violent and Aggressive Youth. Intervention and Prevention Strategies for Changing Times. California. Corvin Press inc.

Brenner, C. (1998). Psikanaliz. Temel kavramlar. (Çev. I. Savaşır, Y. Savaşır). Ankara: Hekimler Birliği Yayınları.

Budak, S. (2000) Psikoloji Sözlüğü. Ankara: Bilim ve Sanat Yayınları.

Deffenbacher, J. L. (1999). Cognitive behavioral conceptualization and treatment of anger. Journal of Clinical Psychology, 22, Web: 1.www.Epnet.com.

Dykeman, B. F. (1995). The social cognitive treatment of anger and aggression in four adolescents with conduct disorder. Journal of Instructional Psychology. (22). 194-203.

Gazda, G. M. (1995). Human relations development. Boston. Simon and Schuster Company.

Geçtan, E. (1990). Varoluş ve psikyatri. İstanbul: Remzi.

Geçtan, E. (1993). Psikanaliz ve sonrası. İstanbul: Remzi

Geçtan, E. (1997). Insan olmak. İstanbul: Remzi.

Gentry, W.D. (2000). Anger free. Ten basic steps to maneging your anger. New York: Harper Collins Publisher inc.

Groves, P. M. Schlesinger, K. (1982). Introduction to biological psychology. USA: Wm. C. Brovn publisher company.

Lulofs, R. S.\& Cahn, D. D. (2000) Conflict from theory to action. United States of America: Aperson Education Company.

Mayne, J. T., Ambrose, K. (1999). Research review on anger psychotherapy. Journal of Clinical Psychology, 55 (3) 353-363. 
Morris, G.C. (2002). Psikolojiyi anlamak. (çev. H. Belgin Ayvaşı;; Melike Sayıl). Ankara: Türk Psikologlar Derneği Yayınları. No:23 .

Novaco, R. W. (1975). Anger control. Canada. D.C: Health and Company.

Ohrnstein, P. H.(1999) Conceptualization and treatment of rage in self psychology. Journal of Clinical Psycology .55 (3), 283-293.

Özer, A. K. (1994a). Öfke, kaygı ve depresyon eğilimlerinin bilişsel alt yapısıyla ilgili bir çalışma. Türk Psikoloji Dergisi, 9 (31), 2-35.

Tsai, P. C. (2000). The lived experienced of anger in childeren. (Thesis/Dissertation, PhD.). Calgary, Alberta: Department Of Educational Psychology. https://dspace.ucalgary.ca/handle/1880/40455

Türkiye Bilimler Akademisi Raporları 4. ( 2004). Ergen ve ruhsal sorunlarl. Durum saptama çalışması. Ankara: TUBA yayınları.

Türk Dil Kurumu (1988). Türkçe Sözlük. Atatürk Kültür Dil ve Tarih Yüksek Kurumu Yayınları. : Yayın no 549. Cilt 2: Ankara

Westermayer, R. W. (2001). November, 2004 http: //www.habitsmart.com/ anger.html. 